\section{An International Year to Celebrate Nursing}

María de los Ángeles Rodríguez Gázquez

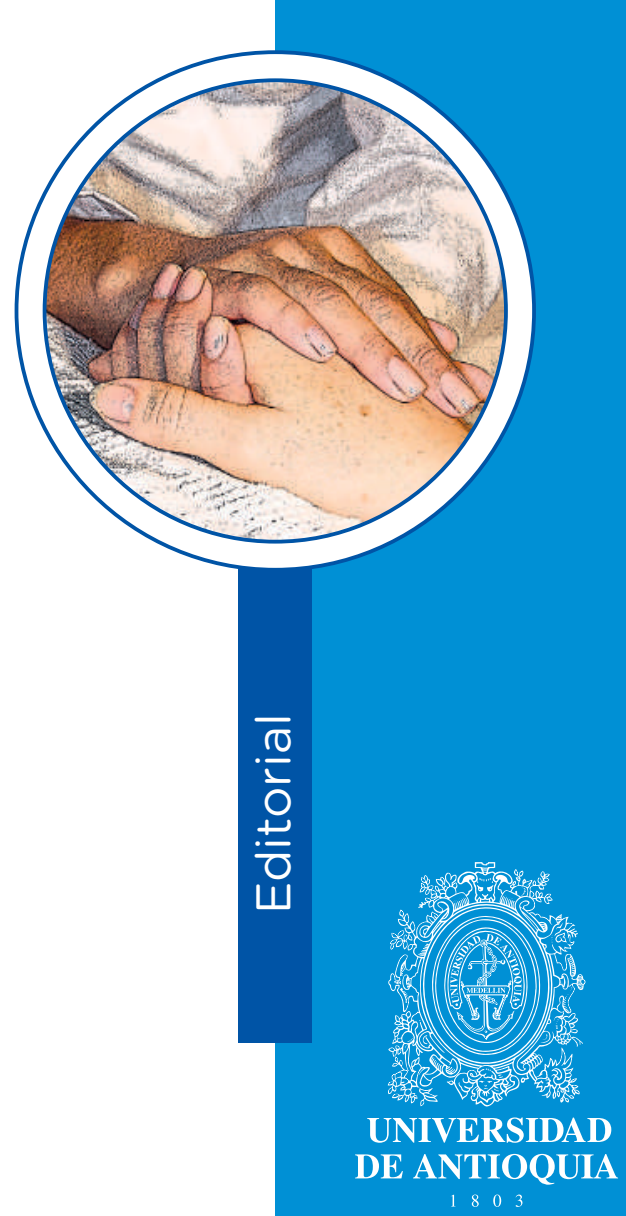

1 Editor of Investigación y Educación en Enfermería. Universidad de Antioquia, Colombia.

Email: maria.rodriguezg@udea.edu.co

How to cite this article: Rodríguez MA. An International Year to Celebrate Nursing. Invest. Educ. Enferm. 2020; 38(1):e01.

DOI: $10.17533 /$ udea.iee.v38n1e01
The 2020 initiative: International Year of Nursing is Midwives, the International Nurses Council, the campaign Nursing Now, and the United Nations Population Fund. Throughout the year and globally activities will be undertaken to celebrate the work of nursing and which

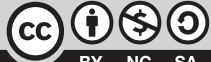


show to public opinion the difficult conditions these professionals encounter, situations that must be improved by promoting investment to increase training and employment of this personnel as part of each country's commitment with health for all. ${ }^{(2)}$

For 38 years, our journal, Investigación y Educación en Enfermería, has exalted the essential role of nurses in caring for individuals and communities, and will continue supporting efforts on the dissemination of knowledge to collaborate in the growth of this discipline, which, although young, presents a wealth of research as never seen before. ${ }^{(3)}$ By this means our readers, authors, reviewers and members of the Editorial Committee are invited to, and not only for this year, write and publish about what they think, feel, and do for Nursing to help to make this world become a bit better each day.

Happy International Year of Nursing

\section{References}

1. World Health Organization. 2020: International Year of the Nurse and the Midwife Report by the Director-Genera. Geneve: WHO. 2019 [cited 21 Jan 2020]. Available from: http://apps.who.int/gb/ebwha/pdf_files/WHA72/ A72_54Rev1-en.pdf

2. World Health Organization. Year of the Nurse and the Midwife 2020. Geneve: WHO. 2019 [cited 21 Jan 2020 ]. Available from: https://www.who.int/en/news-room/campaigns/year-of-the-nurse-and-the-midwife-2020

3. Rodríguez-Gázquez. MA, Chaparro-Hernández SJ, Rojas-Minota WM. Scientific production of the journal Investigación y Educación en Enfermería during its 30 editing years. Invest. Educ. Enferm. 2013;31(3):341-53. 